\title{
EFFECT OF CARBON TAX AND ELECTRICITY BUY-BACK ON THE OPTIMAL ECONOMIC ADOPTION OF PV SYSTEM FOR RESIDENTIAL BUILDINGS
} 住宅太陽光発電システム経済最適化における炭素税及び逆潮流の影響に関する分析

\author{
Hongbo REN*, Weijun GAO**, Yingiun RUAN ${ }^{* * *}$ and Toshiyuki WATANABE H*** $^{* *}$ \\ 任 洪 波, 高 偉 俊, 阮 応 君, 渡辺俊行
}

\begin{abstract}
Photovoltaic (PV) systems have been introduced around Japan for the energetic, economic and ambient benefits, and expected to be diffused more and more. The nation target for PV capacity in Japan is $4.82 \mathrm{GW}$ in 2010. To achieve the target, several support programs, such as subsidization to capital cost, green credit and electricity buy-back, have been already introduced. Carbon tax is still under consideration, but there have been several researches about its feasibility and viability. Ministry of the Environment said in a statement that the tax should be 2.4 Yen/kg-C.

In this paper, five scenarios with various carbon tax rates and electricity buy-back prices for the adoption of grid-connected PV system in residential buildings have been studied. A previously developed evaluation model MinSC has been employed for analysis. The effect of carbon tax and electricity buy-back price on economic benefits of PV system in residential buildings has been discussed. The result indicates that there is an optimal PV capacity for a certain scenario when considering the minimum annual energy cost. And both carbon tax and electricity buy-back stimulates the adoption of PV system. However, the carbon tax makes the PV system better off in a relative sense and results in absolute cost increase.
\end{abstract}

Keywords: Photovoltaic, Optimization, Residential application, Carbon tax, Electricity buy-back 太陽光発電，最適化，住宅，炭素税，逆潮流

\section{Introduction}

In 21 st century, sustaining development and global environmental protection are the important themes of human beings. In order to prevent from global warming, an important measure is to reduce greenhouse gas emissions. Therefore, the searching for a substitute for fossil energy sources has increased the interest in PV system as a long-term, inexhaustible, environmentally friendly and reliable energy technology. The main advantages of PV system include: reasonable conversion efficiency, efficiently integrated in buildings, high reliability and long lifetime, as well as low maintenance cost and low environmental load. PV system has been proved to be an effective option in helping countries to meet their $\mathrm{CO}_{2}$ reduction and renewable energy generation targets. In the last few years, the global installation of PV system has increased steadily at an average of $30 \%$ per year. In 2003 , the total installed capacity of PV installation in the world reached 1,242 MW, among which Japan had a share of $860 \mathrm{MW}$, more than $69 \%$. In Japan, the security of Japanese energy supply and the commitment under the Kyoto Protocol to reduce its greenhouse gas emission by $6 \%$ at the end of 2010 , compared to the 1990 level, are the main reasons for the accelerated development and research of PV system. The Japanese government is making solar energy an important part of its overall energy mix, with a goal of 10 percent electricity production from PV by 2030. To achieve the target, several support programs, such as subsidization to capital cost, green credit and electricity buy-back, have been already introduced. Faced with commitments and deadlines, government is no longer relying solely upon positive incentives for renewable energy, but is increasingly turning to disincentives for consumption of energy forms with undesirable characteristics. A carbon tax is such a policy, although still under consideration in Japan, there has been much research examined its feasibility and viability. Ministry of the Environment said in a statement that the tax should be $2.4 \mathrm{Yen} / \mathrm{kg}-\mathrm{C}$. However, in some European countries, the carbon tax is relatively high. For example, in the Netherlands, the tax rate is $5 \mathrm{Yen} / \mathrm{kg}-\mathrm{C}$ for electricity. Furthermore, a higher tax rate of about $20 \mathrm{Yen} / \mathrm{kg}-\mathrm{C}$ is adopted in Sweden for natural gas ${ }^{1-5}$. In Japan, the carbon tax research committee has studied the possible tax rate between 6 Yen $/ \mathrm{kg}-\mathrm{C}$ and $15 \mathrm{Yen} / \mathrm{kg}-\mathrm{C}$, and analyzed its effect on the reduction of carbon emissions ${ }^{6}$.

Individual homeowners are the most common PV buyers in Japan, comprising nearly 90 percent of the market. In the process of introducing a PV system, one of the most important problems faced by building owners is whether the PV system can bring economic benefits for their buildings. Much work has been reported on this topic. José $\mathrm{L}$ and Rodolfo ${ }^{\text {}}$ analyzed the economic and environmental aspects of grid connected PV systems using the Life Cycle Analysis theory. M. Oliver and T. Jackson ${ }^{8)}$ assessed the application of building integrated PV system
${ }^{*}$ Ph. D. Candidates, The Univ. of Kitakyushu, M. Eng.

** Prof., The Univ. of Kitakyushu, Xi'an Jiaotong Univ., Jilin Archit. And Civil Eng. Institute, Dr. Eng.

*** Special Researcher, Kyushu University, Dr. Eng.

**** Prof., Kyushu University, Dr. Eng.
北九州市立大学大学院 博士後期課程

北九州市立大学・西安交通大学・吉林建築工程学院 教授・工博

九州大学大学院人間環境学研究院 JSPS研究員 - 工博

九州大学大学院人間環境学研究院 教授. 工博 
applying energy and economic analysis. J. Byme" assessed the economic viability of PV from demand-side management perspective. $\mathrm{R}$ Goto et al. ${ }^{10)}$ analyzed the optimum sizes of a hybrid PV and fuel cell system. However, very little research is spent on the sensitivity analysis of optimal PV adoption to different economic conditions, especially some newly emerging policies.

In this paper, five scenarios with various economic conditions for the adoption of PV system are assumed. Optimal PV system capacity for each scenario is achieved by using an evaluation model MinSC, which has been previously constructed in an optimization software package LINGO ${ }^{11-12}$. Based on the simulation results, various scenarios are evaluated and compared regarding annual energy cost, payback period, etc. Furthermore, the influence of carbon tax and electricity buy-back on the economic benefit of PV system is analyzed.

\section{Methodology}

An economic optimization model has been developed in previous research ${ }^{12)}$. In this paper, using this model, the economic aspects of PV adoption have been analyzed.

\subsection{Model description}

The model evaluates the economic aspects of PV system in the residential buildings. The objective function is to minimize annual energy cost, including PV investment cost, maintenance cost, utility electricity cost, carbon tax cost, subtracting the revenue from selling the excess electricity. As shown in Fig. 1, it takes the customer's selections (e.g. PV capacity, etc), combines them with pre-collected data (electric rate schedules, carbon tax rate, government economic incentives, local weather data, electric load profiles, and PV system performance) and analyzes the information using time series analysis. Finally, overall evaluation results regarding energy cost, payback period and other economic effects can be obtained, according to the simulation for various scenarios.

\subsection{Assessment indexes}

In order to evaluate the PV economics in residential buildings, the following indexes are defined:

(1) Annual energy cost

Annual energy cost is defined as the total cost for the building to meet its energy requirement. The turn-over is the income from selling electric power at the spot market $C_{\text {sale }}^{P V}$. The costs include the followings: the cost for buying electric power from the spot market $C_{p u r}^{P V}$, the cost for maintenance of the system $C_{n u r}^{P V}$, system investment cost (excluding the subsidies) $C_{s y s}^{P V}$, and the cost for carbon emission $C_{c l a x}^{P V}$. It can be described as follows:

$$
C_{\text {total }}^{P V}=C_{s y s}^{P V}+C_{r u n}^{P V}+C_{p u r}^{P V}+C_{c t a x}^{P V}-C_{\text {sale }}^{P V}
$$

System cost is illustrated in Eq. (2). It is calculated according to the annualized capital cost. Annualizing capital means to spread the initial cost of an option across the life time of that option while accounting for the time value of money. The cost of capital is annualized as if it were being paid off as a loan at a particular interest of discount rate over the life time of the option. The result is a future value cost or constant annual cost of capital.

$$
C_{s y s}^{P r}=(C C-S) \cdot C P \cdot \frac{I}{\left(1-\frac{1}{(1+I)^{T}}\right)}
$$

Where $C C$ and $C P$ are capital cost per capacity and the capacity of PV system, respectively. $S$ is the subsidies, $I$ is the real interest rate, $T$ is the

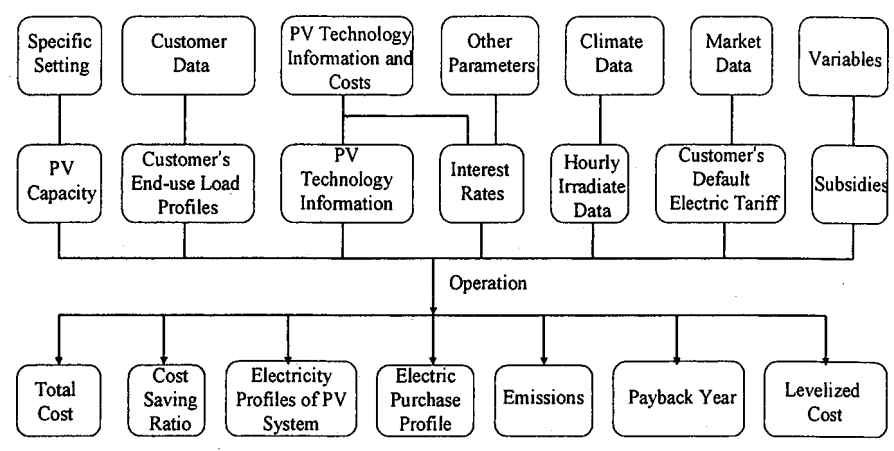

Fig. 1. Model flow chart

life time of PV system.

The running cost is calculated according to Eq. (3). It is assumed to be proportioned to the system initial cost and calculated by multiplying a coefficient $\alpha$.

$$
C_{\text {run }}^{P V}=C C \cdot C P \cdot \alpha
$$

The cost for purchased electricity and income from selling electricity to the grid are described by Eqs. (4) and (5), respectively.

$$
\begin{aligned}
& C_{u t i i t y}^{P V}=E_{\text {pur }} \cdot P_{\text {pur }} \\
& C_{\text {sale }}^{P V}=E_{\text {sal }} \cdot P_{\text {sal }}
\end{aligned}
$$

Where $E_{\text {pur }}$ and $E_{\text {sal }}$ are the amount of electricity purchasing and selling to the grid, respectively, $P_{p u r}$ is the price rate for purchasing electricity (excluding carbon tax) and $P_{\text {sal }}$ is the buy-back price rate.

The cost for carbon emission is described as Eq. (6). It is paid for the carbon content of purchased grid electricity.

$$
C_{c l a x}^{P V}=E_{p u r} \cdot C I \cdot C T
$$

Where $C I$ indicates the carbon intensity of grid electricity. $C T$ is the carbon tax rate.

(2) Annual cost saving ratio

Annual cost saving ratio is calculated by comparing with the conventional system which will be specified in the following section, it can be defined as

$$
R t=\frac{C_{\text {total }}^{\text {Conv }}-C_{\text {total }}^{P V}}{C_{\text {total }}^{\text {Conv }}}
$$

Where $C_{\text {lotal }}^{\text {Conv }}$ indicates annual energy cost of the conventional system. (3) Marginal value

Marginal value is composed of marginal cost $M C$ and marginal revenue $M R$, as described in Eqs. (8) and (9). Marginal cost is the additional cost imposed when more capacity is introduced. Marginal revenue is the additional benefits received when more capacity is introduced. Benefits can be expressed in terms of capital amounts, or sometimes satisfaction.

$$
\begin{aligned}
& M C=\frac{\Delta C}{\Delta C P} \\
& M R=\frac{\Delta R}{\Delta C P}
\end{aligned}
$$

Where $\Delta C$ is the additional cost. $\Delta R$ is the additional benefit. $\triangle C P$ is the additional capacity. 
(4) Payback period

The payback period $Y$ is the minimum time which takes to recover investment cost. The payback period for an energy system is calculated as the total investment cost divided by the first year cost saving $C S$, as illustrated in Eq. (10). Simple payback analysis takes into only initial cost and energy savings at present cost. As a common financial tool, it is provided in this paper.

$$
Y=\frac{C P \cdot C C}{C S}
$$

\section{Illustrative example}

In this paper, the site researched is a two-floor residential building in Kitakyushu, Japan, with a total floor area of about $140 \mathrm{~m}^{2}$. It is a wooden frame construction, with the $\mathrm{Q}$ value of $2.70 \mathrm{~W} / \mathrm{m}^{2} \cdot \mathrm{K}, \mathrm{K}$ value of $0.53 \mathrm{~W} / \mathrm{m}^{2} \cdot \mathrm{K}$. The ordinary single-pane window glasses are adopted. The roof angle is $30^{\circ}$ and $\mathrm{PV}$ angle is also $30^{\circ}$ facing the south. The electric air conditioner is adopted for serving the cooling and warming loads and electric heater for hot water supply.

\subsection{Climate data}

The strength of solar radiation is the primary consideration in selecting location for PV installation. In addition, local climate and environment factors such as temperature extremes, humidity, precipitation, and wind will constrain the output of PV array. Nevertheless, they are of little effect compared with irradiation intensity. Therefore, they are neglected. In this study, it is assumed that the electricity output of a PV array is directly proportioned to the irradiation input.

As the third largest of Japan's main islands, Kyushu is famous for its mild climate and geothermal attribute. Kitakyushu is at the tip of northern Kyushu, the summer there can be described as hot and the winter is cool. The hourly mean irradiation in each season is shown in Fig. 2. According to these profiles, annual irradiation is about $1300 \mathrm{kWh} / \mathrm{m}^{2}$ and the irradiation reaches the maximum point at 13:00.

\subsection{Customer data}

In this study, all major applications and loads in the building are assumed to be supplied by the electricity. The detailed load data is given according Liu's research $^{13)}$. It has been simulated in 8760 hours, as shown in Fig. 3. The peak load in winter happens at about 7:00 in the morning, and the loads are relatively large through 17:00 to $22: 00$ in summer.

\subsection{Electricity tariff}

Electric utility service is provided by Kyushu Electric Power Co., Inc ${ }^{(4)}$. Customer purchasing electricity from the utility selects a time of use tariff rate for residential customers (See Table 1). For this tariff type, an electricity charge is

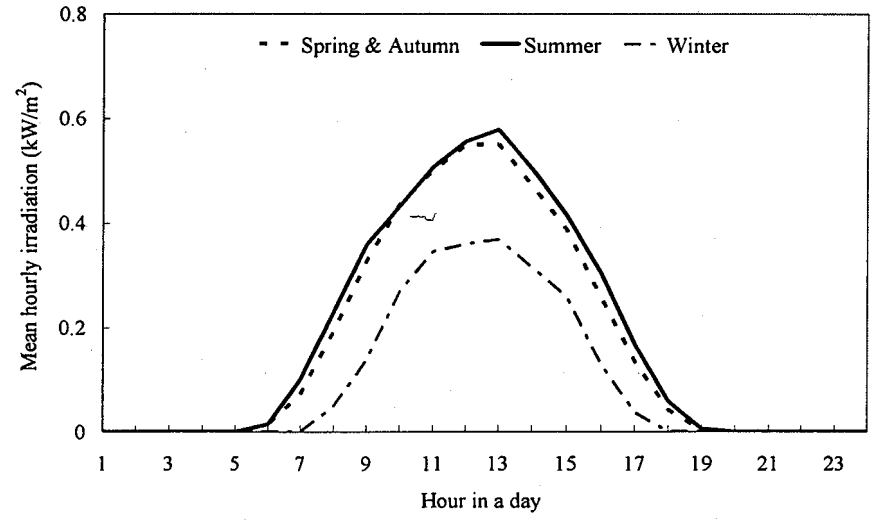

Fig. 2. Hourly mean irradiation in each season imposed a variation by season (where summer months are July through September, inclusive) and load period (on-peak, mid-peak, and off-peak).

\subsection{Other assumptions}

In this study, a grid-connected PV system is assumed. That is to say, PV system can input or output liberally the electricity to the grid, when the amount of generating electricity by PV system excess the demand of users, the surplus electricity can export the electric power back into the grid and otherwise the

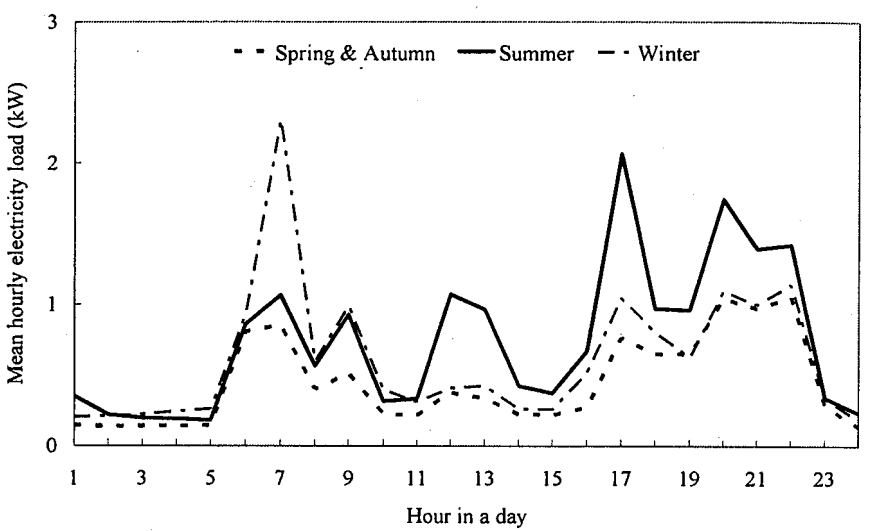

Fig. 3. Hourly mean electricity load in each season

Table 1. Electricity Tariff

\begin{tabular}{cccc}
\hline Season & $\begin{array}{c}\text { Load } \\
\text { Period }\end{array}$ & Hour & $\begin{array}{c}\text { Electricity } \\
\text { Charge } \\
\text { (Yen/kWh) }\end{array}$ \\
\hline \multirow{4}{*}{ Summer } & on-peak & $8-11,13-15,18-21$ & 32.014 \\
& mid-peak & $6-8,11-13,15-18,21-22$ & 20.139 \\
& off-peak & $22-6$ & 7.192 \\
& on-peak & $8-11,13-15,18-21$ & 26.701 \\
Winter & mid-peak & $6-8,11-13,15-18,21-22$ & 20.139 \\
& off-peak & $22-6$ & 7.192 \\
\hline
\end{tabular}

Table 2. Data assumption for the analysis ${ }^{15}$

\begin{tabular}{clc}
\hline & \multicolumn{1}{c}{ Item } & Value \\
\hline Utility & Efficiency $(\%)$ & 36 \\
electricity & Carbon intensity $(\mathrm{kg} / \mathrm{kWh})$ & 0.365 \\
\hline \multirow{3}{*}{ PV system } & Efficiency $(\%)$ & 13 \\
& Rated capacity $\left(\mathrm{kW} / \mathrm{m}^{2}\right)$ & 0.15 \\
& Capital cost per capacity $\left(\times 10^{4} \mathrm{Yen} / \mathrm{kW}\right)$ & 65 \\
& Lifetime (Year) & 30 \\
\hline Others & Interest rate $(\%)$ & 2 \\
\hline
\end{tabular}

Table 3. Scenarios description

\begin{tabular}{ccc}
\hline SCENARIO & $\begin{array}{c}\text { Carbon Tax Rate } \\
(\text { Yen/kg-C) }\end{array}$ & $\begin{array}{c}\text { Buy-back Price } \\
\text { (Yen/kWh) }\end{array}$ \\
\hline SCENARIO 1 & 0 & 20 \\
SCENARIO 2 & 10 & 20 \\
SCENARIO 3 & 20 & 20 \\
SCENARIO 4 & 0 & 15 \\
SCENARIO 5 & 0 & 25 \\
\hline
\end{tabular}


electric utility supplies the shortage of the generating electricity of PV system. Some main assumed data for this analysis is summarized in Table 2.

\section{Scenario description}

In order to evaluate the influence factors of PV adoption, five scenarios with various market and policy conditions of PV adoption have been studied in this paper. The details for five scenarios are listed in Table 3.

Base Scenario is an alternative conventional system. In this scenario, the electricity demand is supplied by the electric utilities.

Scenariol $\sim$ Scenario5 are assumed to use PV system as illustrated in Fig. 4. PV system, associated with the electric utilities, provides the electricity.

Scenario1 is most adjacent to the current Japanese situation, as shown in Table 3. The electricity buy-back price is $20 \mathrm{Yen} / \mathrm{kWh}$ and no carbon tax is adopted.

Scenario2 and Scenario3 have the same buy-back price as Scenario 1. However, they have adopted the carbon tax. The carbon taxes for Scenario 2 and Scenario 3 are $10 \mathrm{Yen} / \mathrm{kg}-\mathrm{C}$ and $20 \mathrm{Yen} / \mathrm{kg}-\mathrm{C}$ respectively.

Scenario4 and Scenario5 have the different buy-back price as Scenario 1. The electricity buy-back price for Scenario 4 and Scenario 5 are $15 \mathrm{Yen} / \mathrm{kWh}$ and 25 Yen/kWh respectively.

\section{Simulation results and discussions}

\subsection{Effect of carbon tax}

Fig. 5 shows annual energy cost for various carbon tax rates. From the profiles, it can be found that each scenario has its optimal PV capacity with $1.5 \mathrm{~kW}$ for Scenario 1, $1.7 \mathrm{~kW}$ for Scenario 2 and $1.9 \mathrm{~kW}$ for Scenario 3. The profiles of the relationship between capacity and marginal value (shown in Fig. 6) are used to explain the reason for occurring optimal capacity. According to these profiles, a rise of capacity leads to a decrease of marginal revenue and the marginal cost is constant, which causes the net marginal benefit to decrease from a positive value to a negative one. At the point where two curves intersect, the customer gets the maximal benefit. That is to say, the PV capacity at the point of intersection is the optimal value for the customer. For example, considering Scenario 1, if the capacity is less than $1.5 \mathrm{~kW}$, then the customer could benefit overall by introduce more. This is because the benefits to the customer (measured by marginal revenue) exceed the costs to him (measured by marginal cost). There will be a net benefit to the customer of the difference between the marginal revenue and marginal cost. Otherwise, if the capacity is greater than $1.5 \mathrm{~kW}$, the customer could benefit by introduce less. This is because when the capacity is reduced, the marginal revenue will increase, which leads to an increase of net marginal benefit. Therefore, the greatest benefit for the maximum capacity occurs at the intersection of marginal cost and marginal revenue.

Furthermore, the optimal capacity increases with the rise of carbon tax rate. When the carbon tax increases from 0 to $10 \mathrm{Yen} / \mathrm{kg}$-C, the optimal capacity increases by $0.2 \mathrm{~kW}$ (from $1.5 \mathrm{~kW}$ to $1.7 \mathrm{~kW}$ ). That is to say, the introduction of carbon tax can accelerate the adoption of PV system because of the clean electricity out of PV system

However, minimum overall energy cost increases with the rise of carbon tax. When the carbon tax is increased to $10 \mathrm{Yen} / \mathrm{kg}-\mathrm{C}$, the minimum overall cost increases about $0.5 \times 10^{4}$ Yen. Similarly, when raising the carbon tax rate to 20 Yen $/ \mathrm{kg}-\mathrm{C}$, Scenario 3 achieves higher cost at $10.6 \times 10^{4}$ Yen, an increase of about $0.9 \times 10^{4}$ Yen more than Scenario 1 .

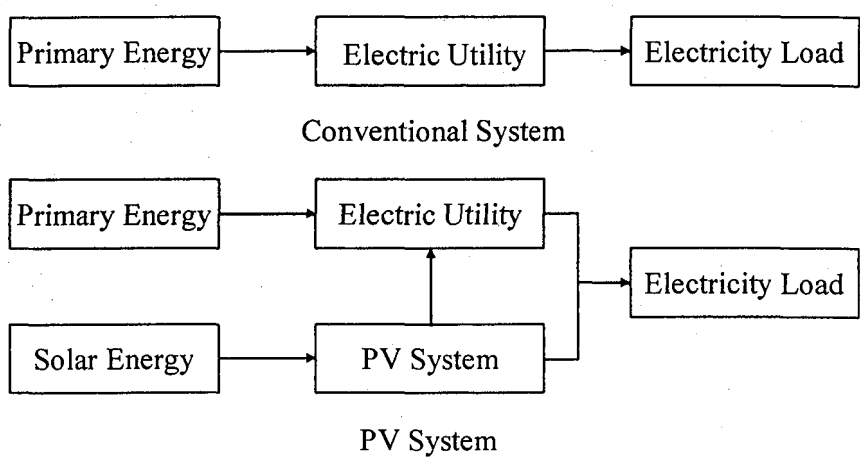

Fig. 4. Electricity flow of conventional system and PV system

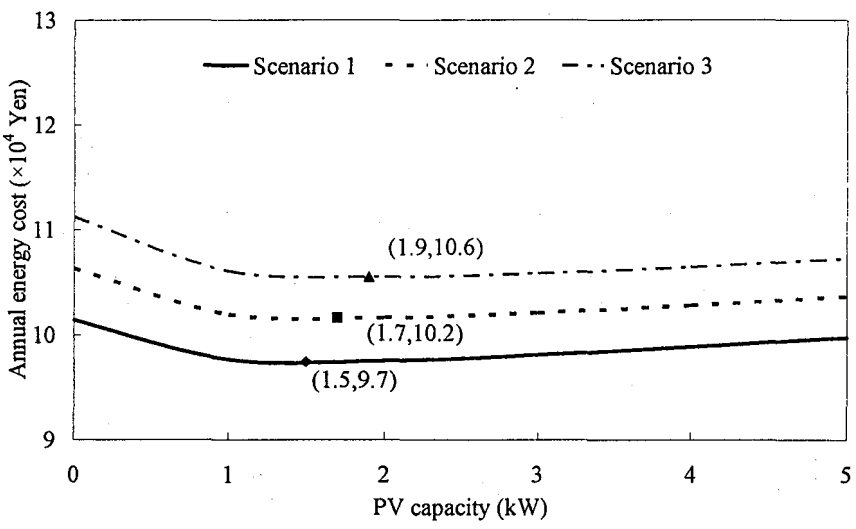

Fig. 5. Annual energy cost for various carbon tax rates and capacities

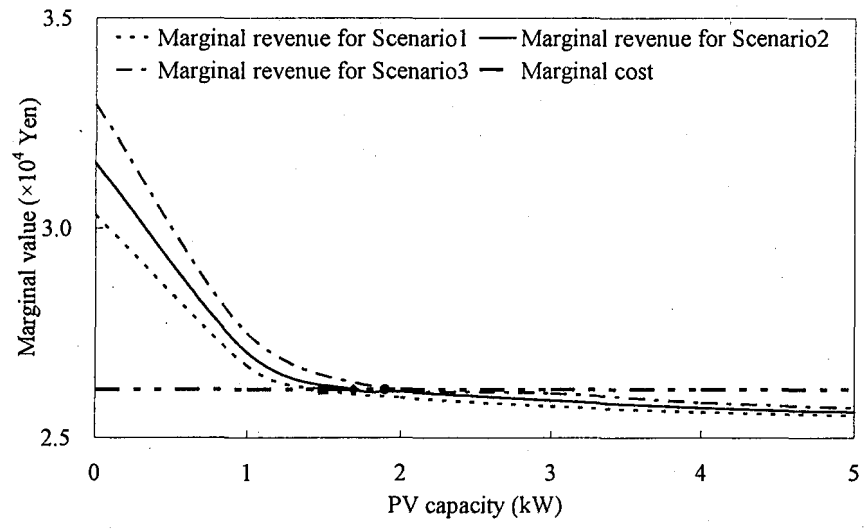

Fig. 6. Marginal value for various carbon tax rates and capacities

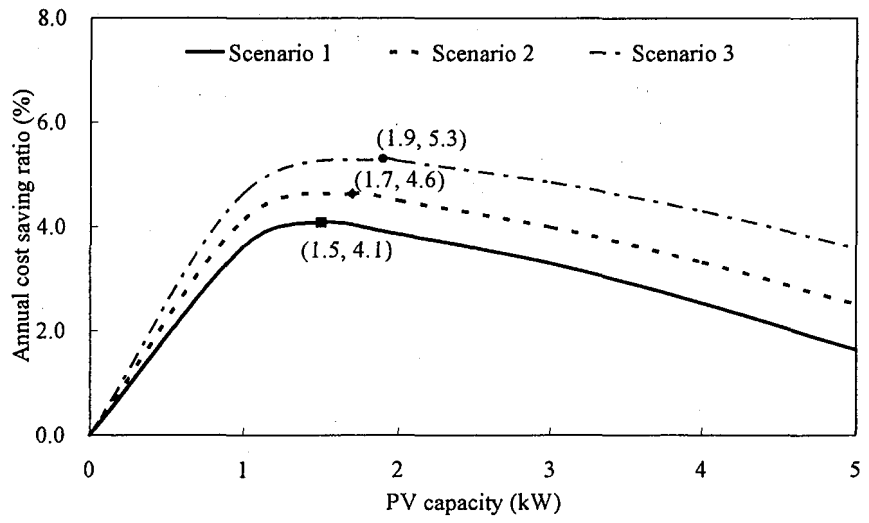

Fig. 7. Annual cost saving ratio for various carbon tax rates and capacities 
Comparing with the conventional system, annual cost saving increases with the rise of carbon tax rate as shown in Fig.7. Scenario 1 gains $4.1 \%$ maximum cost saving ratio, approximately $0.5 \%$ less than Scenario 2 , about $1.2 \%$ less than Scenario 3. From the profiles, it can be found that although the introduction of carbon tax leads to an increase of annual energy cost (as illustrated in Fig. 5), the cost saving ratio is larger than the scenario without carbon tax. This is because the carbon tax cost of PV. system is much less than that of the conventional system, which leads to a relative decrease of annual cost. That is to say, the carbon tax makes the PV system better off in a relative sense (compared to the conventional system), it, nevertheless, results in absolute cost increase.

Fig. 8 is the compare of energy cost composition for different PV capacities with a carbon tax rate of $10 \mathrm{Yen} / \mathrm{kg}-\mathrm{C}$. As expected, the cost for system investment has a linear increase to the capacity. Furthermore, the figure shows that as the increase of capacity, the cost for electricity trade is reduced. When the capacity is increased to $4 \mathrm{~kW}$ or more, the cost for electricity trade turns to a negative value. This is because the revenue from selling electricity back to the grid has exceeded the cost for electricity purchase. In addition, generally, it is found that the carbon tax cost holds only a little part of the total energy cost, even with a relatively high tax rate. With the increase of PV capacity, the carbon tax cost has a reduction, but is not large enough to be seen clearly.

Payback period is a main index for evaluating the economic feasibility. Payback period for various scenarios is shown in Fig. 9. From the profiles, the results can be summarized as follows:

Generally, the payback period increases with the rise of PV capacity. But the increase scope is becoming mild as the further increase of capacity. When a carbon tax is introduced, the payback period has a decrease, but is very limited. This is because of the little part of the carbon tax cost among the total energy cost (see Fig. 8). Furthermore, it can be found that the optimal capacity described above does not lead to the smallest payback period. 5.2 Effects of electricity buy-back

As described above, the grid-connected PV system profits much from electricity buy-back by the grid, so the price for electricity buy-back has great influence on the adoption of PV system. In the following, two scenarios, Scenario 4 and Scenario 5, which have different electricity buy-back prices from Scenario 1, as described in Table 3 , have been illustrated.

Fig. 10 is annual energy cost for various buy-back prices and shows that Scenario 1 has its optimal PV capacity with $1.5 \mathrm{~kW}$, Scenario 4 with $0.5 \mathrm{~kW}$. However, Scenario 5 does not show an obvious optimal value with least annual energy cost. This is because the high buy-back price makes the adoption of PV system very attractive until the maximum capacity, which is determined by the available roof area. As described above, the relationship between capacity and marginal value (shown in Fig. 11) explains the reason for occurring optimal capacity.

As shown in Fig. 11, the marginal costs for various scenarios are the same, and the marginal revenue has an increase as the rise of buy-back price, which causes the intersection to move to the right. That is to say, a rise of buy-back price leads to an increase of optimal PV capacity. For Scenario 5, the marginal revenue is always above the marginal cost, which means it is economic to adopt PV system as large as possible.

From above analysis, it can be found that electricity buy-back price greatly affects the economics of PV system. This can be explained using Fig. 12. As

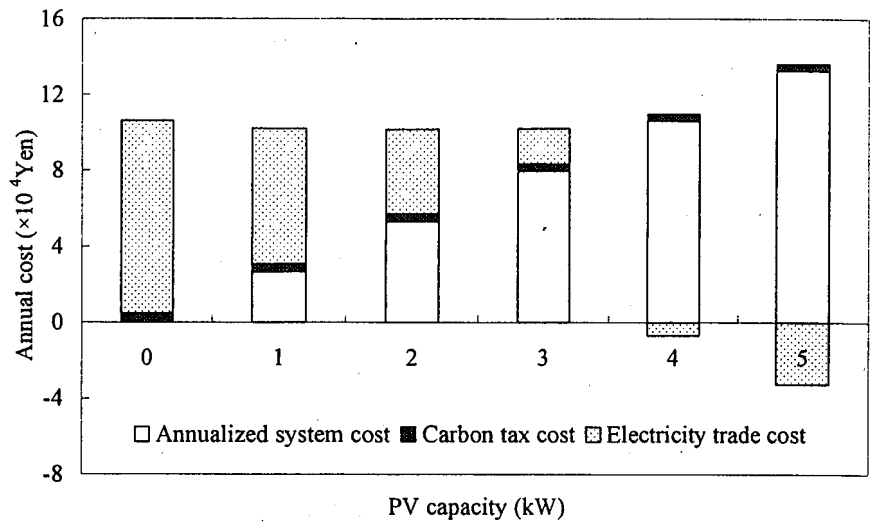

Fig. 8. Annual cost composition for various capacities of Scenario 2

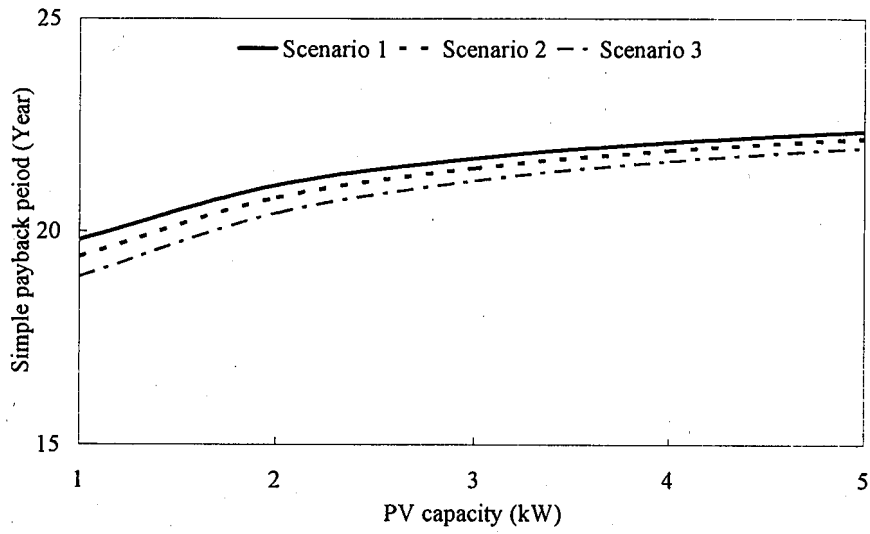

Fig. 9. Simple payback period for various carbon tax rates and capacities

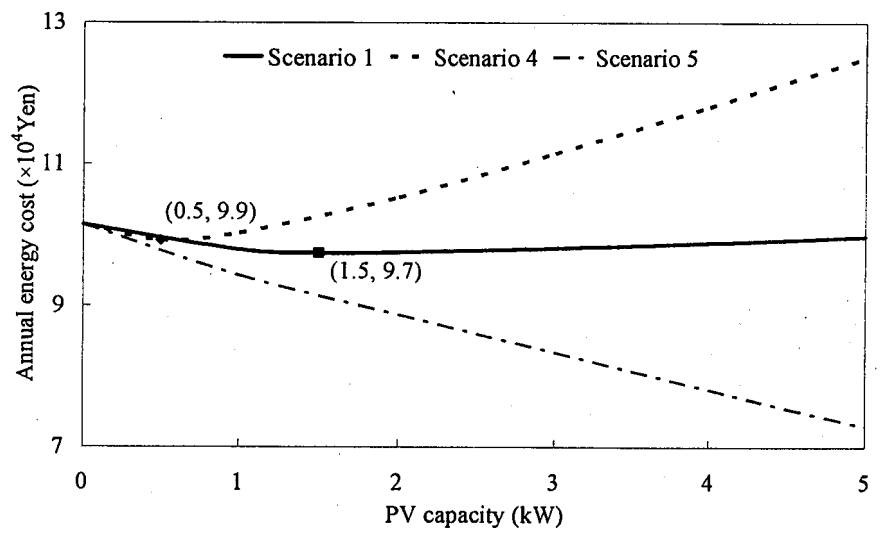

Fig. 10. Annual energy cost for various buy-back prices and capacities

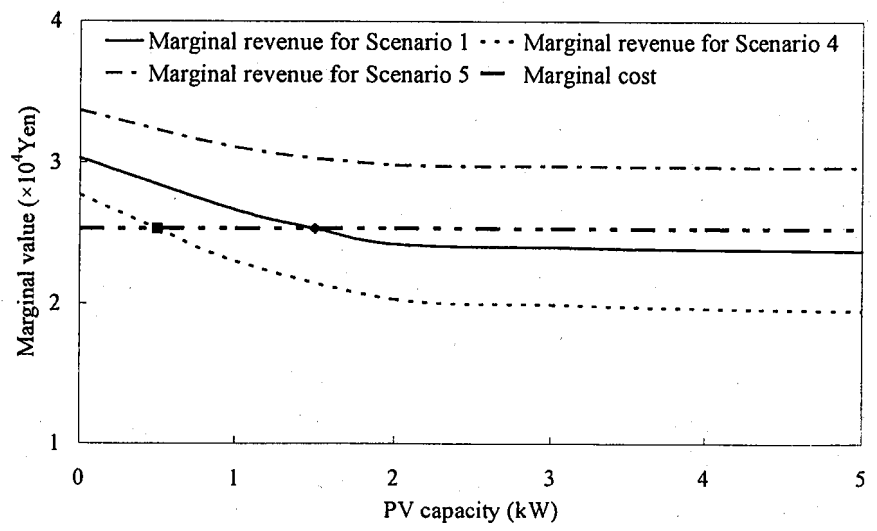

Fig. 11. Marginal value for various buy-back prices and capacities 


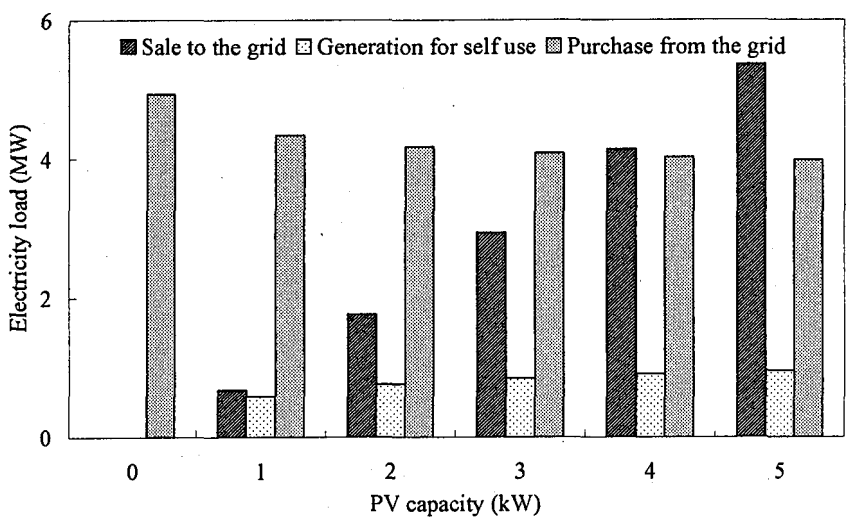

Fig. 12. Electricity load composition for various capacities of Scenario 1

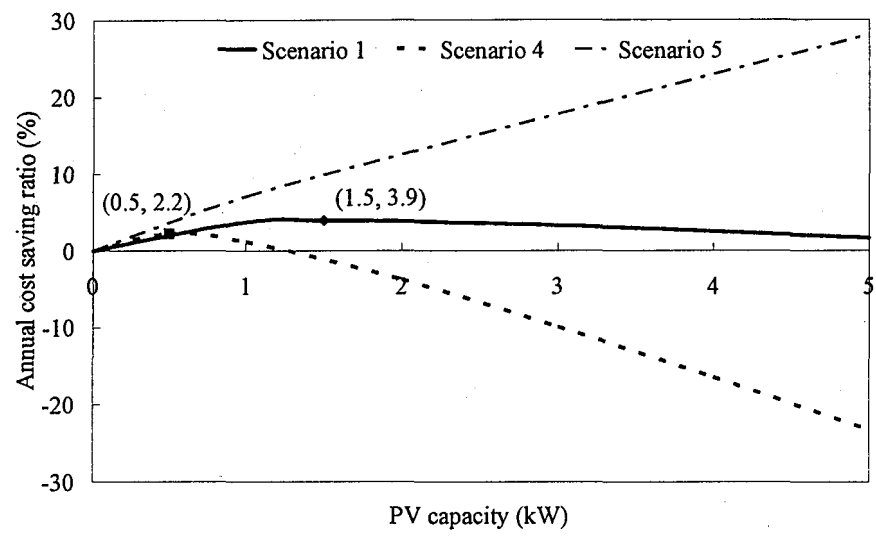

Fig. 13. Annual cost saving ratio for various buy-back prices and capacities

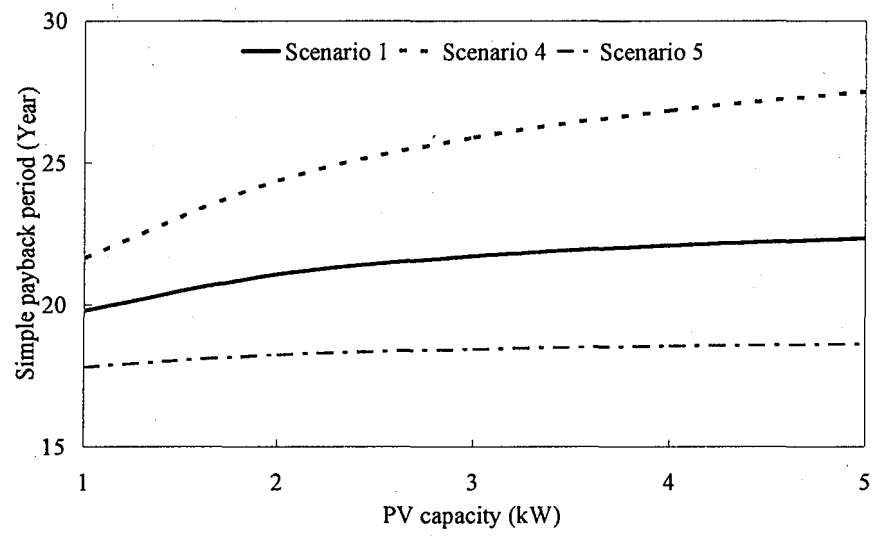

Fig. 14. Simple payback period for various buy-back prices and capacities

shown in this figure, the part of PV system output used for customer self use has little change with the increase of capacity. Also, it can be seen that the electricity purchased from the grid decreases as the increase of capacity, but the amount is becoming less and less. However, the electricity buying back by the grid has obvious increase as the adoption of more capacity. When the capacity reaches 4 $\mathrm{kW}$, the buy-back electricity even excesses the electricity purchase.

Less annual energy cost means higher cost saving. Therefore, cost saving ratio has the adverse profile as annual energy cost. Fig. 13 is the cost saving ratio for various electricity buy-back prices and shows that Scenario 1 gains $4.0 \%$ maximum cost saving ratio, approximately 1.7 point more than Scenario 4 . In addition, for Scenario 4, when the capacity reaches $1.3 \mathrm{~kW}$ or more, the cost saving ratio turns to a negative value, which means the low buy-back price reduces the attraction of PV system greatly.
Fig. 14 is the payback period for various buy-back price and capacities. The buy-back price has great effect on the payback period, an increase of $5 \mathrm{Yen} / \mathrm{kWh}$ leads to a decrease of payback period between 2 to 7 years. In addition, as the increase of buy-back price, the payback period becomes less sensitive to the capacity.

\section{Conclusions}

In this paper, the PV economics in residential buildings has been assessed by analyzing various scenarios. The analysis is carried out using a previously constructed evaluation model. The results can be summarized as follows:

1) For a practical project, each scenario has its optimal PV capacity, considering the minimum annual energy cost.

2) The introduction of carbon tax stimulates the adoption of PV system However, it makes the PV system better off in a relative sense and results in absolute cost increase. The optimal capacity has an increase of $0.2 \mathrm{~kW}$ with the adoption of a carbon tax of $10 \mathrm{Yen} / \mathrm{kg}$-C. Correspondingly, annual energy cost increases $0.5 \times 10^{4}$ Yen and the relative cost saving has a rise from $4.1 \%$ to $4.6 \%$ at the optimal point.

3) Electricity buy-back price has a positive influence on PV adoption. With a price of $25 \mathrm{Yen} / \mathrm{kWh}$, the customer prefers to adopt the maximal PV capacity limited to the available roof area. However, as the price is reduced to 15 Yen $/ \mathrm{kWh}$, the economic attractive investment is between 0 and $1.3 \mathrm{~kW}$.

\section{References}

1) The expert group on renewable energy convened by the United Nations department of economic and social affairs: Increasing global renewable energy market share: recent trends and perspectives, U.S.A.: the United Nations, 2005.12

2) New energy and industrial technology development organization (NEDO): Overview of "PV Roadmap Toward 2030", Japan: NEDO, 2004.6

3) Robort Foster: Japan Photovoltaic market overview, U.S.A.: New Mexico State University, pp.1-10, 2005.10

4) Qingrong Liu, Yuji Ryu, Weijun Gao, Yingiun Ruan: Field study and sensitive analysis of PV system by multiple regression method, Journal of Asian Architecture and Building Engineering, Vol.3(2), pp. 247-252, 2004.11

5) Ministry of the Environment: Concrete idea about environmental tax, Japan, 2005

6) Carbon tax research committee: Towards the early introduction of carbon tax, Japan: Japan Center for a Sustainable environment and Society, 2006

7) José L. Bernal-Agustín and Rodolfo Dufo-López: Economical and environmental analysis of grid connected photovoltaic systems in Spain, Renewable Energy, Vol.31(8), pp.1107-1128, 2006.7

8) M. Oliver and T. Jackson: Energy and economic evaluation of building-integrated photovoltaics, Energy, Vol.26(4), pp. 431-439, 2001.4

9) J. Byme: Evaluating the economics of photovoltaics in a demand-side management role, Fuel and Energy Abstracts, Vol.37(2), pp.118, 1996.2

10) R. Goto, Y. Hamada, H. Kubota, M. Nakamura, K. Ochifuji and M. Murase: Study on hybrid utilization of renewable energy and fuel cell for residential energy system Part 3Experiments and analyses on hybrid system using solar energy and fuel cell, Transaction of SHASE, No. 106, pp. 1-10, 2006.1

11) LINDO Systems Inc.,; Lingo User's Guide, USA, 2005.5

12) Hongbo Ren, Weijun Gao and Yingjun Ruan: Optimal sizing of grid connected photovoltaic systems for residential application, The Yellow Sea Rim International Exchange Meeting on Building environment and Energy 2007, pp.175-183, 2007.1

13) Qingrong Liu: Research on the high efficiency energy utilization and supply system for residence, Ph.D. thesis, The University of Kitakyushu, 2007.3

14) Kyushu Electric power co., inc.: Electricity contracts for residential customers, 2007

15) Ministry of the Environment: Carbon emission coefficients for various electric companies in 2005, Japan, 2007 


\section{和文要約}

1. はじめに

本論文では、太陽光発電（以下 PV と略す）の普及に寄与することを目 的とし、住宅における PV システム導入の経済最適化に関する研究を行っ た。PV システムの経済性シミュレーションモデル（MinSC）を構筑し、 住宅における PV システムを導入する場合、炭素税及び逆潮流の影響を分 析した。ケースを5つに設定し、それぞれのケースの年間エネルギーコス ト、エネルギーコスト削減率及び回収年数への影響を評価し、炭素税及び 逆潮流が PV システムに与える影響を定量的に分析した。

\section{2. シミュレーションと評価方法}

本論文では、PVシステム導入の経済性シミュレーションモデル(MinSC) を構築した。MinSC は著者らが開発した PV システムの経済解析ツールで ある。このツールには、目的関数は、PV の初期投資、メインテナンス費、 買電コスト、炭素税費、売電収入などを含んでいる年間エネルギー総コス トを最小にすることである。図 1 に示すように、顧客の情報（例えば、PV 容量など）を選んで、電気料金スケジュール、炭素税、政府補助、気象デ 一夕、電力負荷、PVシステムなど情報を入力することにより、MinSC は 年間運転状況をシミュレーションするとこができ、年間エネルギーコスト、 発電価格及び回収年数などを計算することができる。

3. モデル入カ

3.1 気象データ

本論文では、2003 年の北九州の日射データを採用した。季節別の平均時 刻日射量は図 2 に示す。年間日射量は約 $1,300 \mathrm{kWh} / \mathrm{m}^{2}$ である。

\section{2 負荷デ一タ}

本論文では、全電化住宅を対象としており、詳細負荷データは劉らの研 究 ${ }^{13}$ から採用した。負荷データはモデル住宅に対し、空気調和・衛生工学 会による生活スケジュールを利用して、8760h の家電、照明および給湯な どの負荷を予測した。図3では季節別の電気負荷曲線を示している。

\section{3 電気料金}

本論文では、九州地区を対象とし、表 1 に示すような九州地区の電力価 格を使用している。

\section{4 他の要素設定}

他の初期データは表 2 に示している。

\section{4. ケース設定}

本論文では表 3 に示すような五つのケースを設定している。ベースケー スは図 4 のような従来システムで、商用電力で電力を供給する。ケース 1 〜ケース 5 は図 4 のような PV システムを採用し、PV システム及び商用電 力を用いて、電力を供給する。本研究では、系統電力からの買電及び PV システムによる系統電力への売電が自由に行われることを仮定した。

ケース 1 では、日本の現状と最も似ているケースで、炭素税が導入して いない。

ケース 2 とケース 3 はケース 1 と同じ売電価格だが、炭素税が違う。ケ 一ス 2 の炭素税は $10 \mathrm{Yen} / \mathrm{kg}-\mathrm{C}$ に対し、ケース 3 の炭素税は $20 \mathrm{Yen} / \mathrm{kg}-\mathrm{C}$ と 仮定した。

ケース 4 とケース 5 はケース 1 と同じ炭素税だが、売電価格が違う。ケ ース 4 の売電価格は $15 \mathrm{Yen} / \mathrm{kWh}$ に対し、ケース 5 の売電価格は $25 \mathrm{Yen} / \mathrm{kWh}$ と仮定した。

\section{5. 結果分析}

\section{1 炭素税の影響分析}

図 5 は炭素税別の年間エネルギーコストを示している。三つの炭素税に
も、年間総コストが最小となる最適な PV 容量が存在し、それぞれ最適な PV 容量は $1.5 \mathrm{~kW} 、 1.7 \mathrm{~kW}$ と $1.9 \mathrm{~kW}$ である。理由として、図 6 に示すよう に、発電容量の増大につれ、限界収益（発電容量単位当たりの収益変化） が减少し、限界コスト（発電容量単位当たりのコスト変化）が変わってい なかったので、純限界収益（限界収益 - 限界コスト）がプラスからマイ ナスに減少していく。限界収益と限界コスト 2 つ曲線の交差点では、顧客 が最大限度の利益を得る。また、太陽光発電は環境に優しく、炭素税費用 がないため、炭素税の増加につれ、最も経済的な最適発電容量がしだいに 増大していく。しかし、炭素税の増大につれ、年間エネルギ一費用が増大 していく。

図 7 は炭素税別の年間エネルギーコスト削減率(従来システムに比べる) を示している。最大年間エネルギーコスト削減率はそれぞれ $4.1 \%, 4.6 \%$ と $5.3 \%$ である。炭素税を導入すると、ケース 2 の最大年間エネルギーコスト 削減率はケース 1 より $0.5 \%$ 高くなっている。炭素税が倍になると、最大年 間エネルギーコスト削滅率は約 $1.2 \%$ 増加していく（ケース 1 とケース 3 に比べる)。そして、炭素税の導入はPVにとって相対的に利益が与えられ るが、絶対年間コストが増大寸る。

図 8 はケース 2 の年間コスト構成を示している。発電容量の増大につれ、 投資費用が線形的に増大する。また、炭素税費用は全体の費用の割合が小 さい。

図 9 は単純の回収年数である。炭素税の増大につれ、回収年数が減少し ていくが、炭素税費は他のコストに比べて比較的小さいため、回収年数に 与える影響は限定的である。

\section{2 逆潮流の影響分析}

図 10 には、売電価格別の各ケースの年間エネルギーコストを示してい る。ケース 1 （売電価格 $20 \mathrm{Yen} / \mathrm{kWh}$ ）に比ベ、ケース 4 （売電価格 15 $\mathrm{Yen} / \mathrm{kWh}$ ）の最適の PV 容量が $1.0 \mathrm{~kW}$ 減少した。売電価格は $25 \mathrm{Yen} / \mathrm{kWh}$ （ケース 5）になると、発電容量を增加するほど、顧客の年間エネルギー コストが減少していくため、最大の発電容量は屋根面積により決められる。 この理由は炭素税の影響と同様に、限界収益と限界コストの変化により純 限界収益を決められるためである（図 11）。

図 12 はケース 1 の電気負荷構成を示している。発電容量の増加につれ、 売電量の増大が顕著である。そのため、売電価格が年間エネルギーコスト に与える影響が大きい。

図 13 は売電価格別の年間エネルギーコスト削減率（従来システムに比 ベる）を示している。ケース 1 とケース 4 の最大年間エネルギーコスト削 減率はそれぞれ $3.9 \%$ 2.2\%である。売電価格が低下すると、ケース 4 の 最大年間エネルギーコスト削減率はケース 1 より 1.7 ポイント減少できる。 売電価格が上昇すると、発電容量の増加につれ、ケース 5 の最大年間エネ ルギーコスト削減率が増加していく。

売電価格別の各ケースの単純回収年数（図 14）を見ると、売電価格のア ップにつれ、回収年数が顕著に減少していく。

\section{6. まとめ}

本論文の結果から、年間エネルギーコストが最小となる最適な PV シス テム容量が存在していることがわかった。炭素税の導入が PV の採用を促 進し、炭素税の増加につれ、最も経済的な最適発電容量は階段式に増大す る。しかし、炭素税の導入はPVにとって相対的に利益が得られるが、絶 対コストが増えてしまう。10Yen/kg-C の炭素税を採用すると、最適の容量 が約 $0.2 \mathrm{~kW}$ 増加する。同時に、年間エネルギーコストが 5 千円増大する。

また、逆潮流はPV 採用に積極的な影響を与える。25 Yen/kWh の売電価 格で、顧客は利用可能な屋根面積まで PV 導入が可能である。売電価格が $15 \mathrm{Yen} / \mathrm{kWh}$ まで下がると、経済的な投資が $1.3 \mathrm{~kW}$ までに限定される。 